\title{
Prospective Study on Prevalence of Vitamin B12 Deficiency in First Trimester of Pregnancy
}

\author{
Sumant R Shah ${ }^{1}$, Urvashi Jain ${ }^{2}$, Vishrut S Shah ${ }^{3}$ \\ BJ Medical College, Civil Hospital, Ahmedabad
}

\begin{abstract}
Gujarat, a state on western coast of India is a state with more than 50\%percentage of vegetarian populationbased on SRS survey 2014.This study was conducted to evaluate the vitamin B12 status of women in first trimester of pregnancy and its relationship with socioeconomic, anthropometric and dietary intake of patient.Low Vitamin B12concentration (<200pg/ml) was observed in $62 \%$ of the women. High maternal body mass index, vegetarian population was associated with significant vitamin B12 deficiency. The level of vitamin b12 deficiency was in only $9.37 \%$ of vegetarian population.The vitamin B12 levels were significantly affected by the demographic factors. $44 \%$ of urban population and $20 \%$ of rural population had normal vitamin B12 levels.A high prevalence of vitamin B12 deficiency was foundin early pregnancy among vegetarian population mainly residing in rural areas. Hence there should be implementation of vitamin b12 routine antenatal testing and administration of vitamin b12 accordingly.
\end{abstract}

Keywords: Vitamin B12; vegetarian population; rural

\section{Introduction}

Gujarat, a state on western coast of India in undoubtedly the state with a higher percentage of vegetarian population. Data based on SRS survey 2014 published by the Registrar General of India reveals that $61.80 \%$ population of the state is vegetarian.

Vitamin B12 also known as cobalamin, is a water soluble vitamin has a key role in the formation and functioning of the central nervous system, and the red blood cells.

Deficiency of vitamin B12 is considered to be highly prevalent in India and signs and symptoms of vitamin B12 deficiency have been reported in $75 \%$ of adult men and women from areas of Western India.

Pregnancy is a critical stage during life cycle where requirement of vitamin B12 increases due to rapid cell multiplication resulting from enlargement of uterus, placental development and fetal growth. Vitamin B12 deficiency is associated with increased risk for adverse fetal outcome including neural tube defects, smallfor gestational age, intrauterine growth retardation, early miscarriage and preeclampsia.In addition to increased requirement during pregnancy, chronic low intake of dietary vitamin B12 and/or parasitic infection and other causes may lead to negative vitamin B12 balance and depletion of tissue stores leading to deficient state. Pregnant woman who are likely to have vitamin B12 deficiency, which leads to low Vitamin B12 level in breast milk and infants with features of vitamin B12 deficiency. Early pregnancy is better time to assess the level of vitamin B12 in maternal serum, since later in pregnancy due to plasma volume expansion there may be reduction in plasma concentration of vitamin B12.

\section{Study Design and Study Population}

A cross sectional study was performed in a group of 100 women in their first trimester of pregnancy taking antenatal visits in obstetrics and gynaecology OPD in Civil Hospital, Ahmedabad, and which is a tertiary care centre predominantly catering to the needs of women coming from low socioeconomic status.Few cases were also included from the periphery for comparative study.Pregnant women aged 18 to 40 years with less than 14 weeks of gestation and registered for antenatal screening were enrolled for the study. Women who were diagnosed with chronic illness like diabetes mellitus, hypertension, heart disease or thyroid disease or who tested positive for HbsAg, HIV or syphilis , multiple gestation, treated for infertility or those who were already taking vitamin B12 supplements were excluded from the study.

\section{Sociodemographic and Anthropometric Information}

Gestational age (in weeks) was calculated from the reported $1^{\text {st }}$ day of last menstrual period (LMP). Weight of all mothers was recorded in kilograms and height in centimetres. BMI was calculated as weight in $\mathrm{kg}$ divided by the square of height in meters. $(\mathrm{kg} / \mathrm{m} 2)$.

\begin{tabular}{|c|c|}
\hline BMI $(\mathrm{kg} / \mathrm{m} 2)$ & Category \\
\hline$<18.5$ & Underweight \\
\hline $18.5-24.9$ & Normal \\
\hline $25-29.9$ & Overweight \\
\hline$\geq 30$ & Obese \\
\hline
\end{tabular}

\section{Dietary Data}

Patient dietary intake was confirmed. Vitamin B12 bioavailability is more in non vegetarian food. Animal sources with significant content of vitamin B12 includes organ meats (liver) from beef, lamb, turkey, fish, eggs etc.

\section{Biochemical Data}

$10 \mathrm{ml}$ of blood is withdrawn from subject by venipuncture and collected in plain vacutainers. The test was carried out by chemiluminescentmicroparicle immunoassay.Normal values are 200 to $900 \mathrm{pg} / \mathrm{ml}$. Low vitamin b12 levels was defined as vitamin B12 level of $<200 \mathrm{pg} / \mathrm{ml}$. 


\section{International Journal of Science and Research (IJSR) \\ ISSN (Online): 2319-7064}

Index Copernicus Value (2015): 78.96 | Impact Factor (2015): 6.391

Statastical Analysis

The data were summarized as means and percentages respectively. Anaemia was defined as $\mathrm{Hb}<11 \mathrm{~g} / \mathrm{dl}$. In the absence of validated cut offs for plasma vitamin B12 concentration in pregnant Indian women, we used cut offs available from the literature. Low vitamin b12 concentration was defined as levels $<200 \mathrm{pg} / \mathrm{ml}$.

\begin{tabular}{|l|c|}
\hline Biochemical char acterstics & $(n=100)$ \\
\hline Haemoglobin $(\mathrm{g} / \mathrm{dl})$ & 9.5 \\
\hline anaemia $(\mathrm{hb}<11 \mathrm{~g} / \mathrm{dl})$ & $62 \%$ \\
\hline Macrocytosis $(\mathrm{MCV}>99 \mathrm{fl})$ & $02 \%$ \\
\hline Anaemia and MCV $>99 \mathrm{flnil}$ & \\
\hline Plasma B12 level $(\mathrm{pg} / \mathrm{ml})(\mathrm{n}=100)$ & 196.6 \\
\hline Low Plasma B12 level $(<200 \mathrm{pg} / \mathrm{ml})$ & $62 \%$ \\
\hline
\end{tabular}

\section{Socio-demographic Characterstics}

Age

\begin{tabular}{|c|c|c|c|}
\hline $\begin{array}{c}\text { Age } \\
\text { (years) }\end{array}$ & $\begin{array}{c}\text { Population } \\
(\%)\end{array}$ & $\begin{array}{c}\text { population with } \\
\text { normal vitamin } \\
\text { B12 }(\%)\end{array}$ & $\begin{array}{c}\text { Population with low } \\
\text { vitamin B12 level } \\
(\%)\end{array}$ \\
\hline$<20$ years & 35 & $37.15(\mathrm{n}=13)$ & $62.85(\mathrm{n}=22)$ \\
\hline $20-25$ years & 42 & $40.48(\mathrm{n}=17)$ & $59.52(\mathrm{n}=25)$ \\
\hline$>25$ years & 23 & $34.79(\mathrm{n}=8)$ & $65.21(\mathrm{n}=15)$ \\
\hline
\end{tabular}

The p-value 0.89. the serum vitamin B12 level in relation to age is not significant at p-value $<0.05$

Residence
\begin{tabular}{|c|c|c|c|}
\hline Residence & $\begin{array}{c}\text { Population } \\
(\%)\end{array}$ & $\begin{array}{c}\text { population with } \\
\text { normal vitamin } \\
\text { B12 }(\%)\end{array}$ & $\begin{array}{c}\text { Population with } \\
\text { low vitamin } \\
\text { B12 level }(\%)\end{array}$ \\
\hline Urban & 75 & $44(\mathrm{n}=33)$ & $56(\mathrm{n}=42)$ \\
\hline Rural & 25 & $20(\mathrm{n}=05)$ & $80(\mathrm{n}=20)$ \\
\hline
\end{tabular}

The p-value is 0.03 . The serum B12 level varies with residence. The deficiency is more prevalent in rural areas at $\mathrm{p}<0.05$.

Occupation
\begin{tabular}{|c|c|c|c|}
\hline Occupation & $\begin{array}{c}\text { Population } \\
(\%)\end{array}$ & $\begin{array}{c}\text { population with } \\
\text { normal vitamin } \\
\text { B12(\%) }\end{array}$ & $\begin{array}{c}\text { Population with } \\
\text { low vitamin } \\
\text { B12 level }(\%)\end{array}$ \\
\hline Unemployed & 87 & $35.64(\mathrm{n}=31)$ & $64.36(\mathrm{n}=56)$ \\
\hline Skilled & 07 & $42.86(\mathrm{n}=03)$ & $57.14(\mathrm{n}=04)$ \\
\hline Others & 06 & $66.67(\mathrm{n}=04)$ & $33.33(\mathrm{n}=02)$ \\
\hline
\end{tabular}

The p- value is0.30. the serum level of vitamin B12 is not significantly associated with occupation at $\mathrm{p}<0.05$.

\section{Education}

\begin{tabular}{|c|c|c|c|}
\hline Education & $\begin{array}{c}\text { Population } \\
(\%)\end{array}$ & $\begin{array}{c}\text { population with } \\
\text { normal vitamin } \\
\text { B12(\%) }\end{array}$ & $\begin{array}{c}\text { Population with } \\
\text { low vitamin B12 } \\
\text { level }(\%)\end{array}$ \\
\hline Illiterate & 60 & $32.67(\mathrm{n}=22)$ & $63.33(\mathrm{n}=38)$ \\
\hline high school & 23 & $34.79(\mathrm{n}=08)$ & $65.21(\mathrm{n}=15)$ \\
\hline $\begin{array}{c}\text { Post high } \\
\text { school/graduate }\end{array}$ & 13 & $59.10(\mathrm{n}=04)$ & $40.90(\mathrm{n}=09)$ \\
\hline
\end{tabular}

The $\mathrm{p}$-value is 0.91 . the association of vitamin B12 level with education is not significant at $\mathrm{p}<0.05$.

Religion
\begin{tabular}{|c|c|c|c|}
\hline Religion & $\begin{array}{c}\text { Population } \\
(\%)\end{array}$ & $\begin{array}{c}\text { population with } \\
\text { normal vitamin } \\
\text { B12 }(\%)\end{array}$ & $\begin{array}{c}\text { Population with low } \\
\text { vitamin B12 level } \\
(\%)\end{array}$ \\
\hline Hindu & 74 & $21.28(\mathrm{n}=15)$ & $79.72(\mathrm{n}=59)$ \\
\hline Muslim & 20 & $85(\mathrm{n}=05)$ & $15(\mathrm{n}=3)$ \\
\hline Christian & 06 & $100(\mathrm{n}=06)$ & Nil $(\mathrm{n}=\mathrm{nil})$ \\
\hline
\end{tabular}

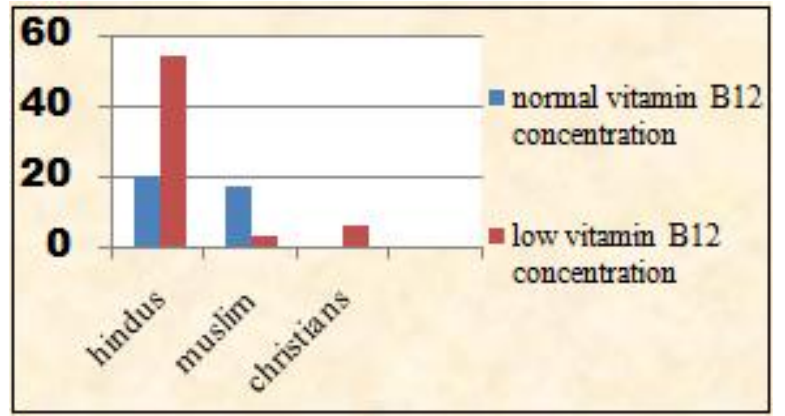

The vitamin B12 levels have a huge religious diversity. $72.97 \%$ of Hindu population has low vitamin B12 levels as compared to $15 \%$ in Muslim population, whereas it is nil in Christian women in their first trimester of pregnancy.

\section{Gestational Age}

\begin{tabular}{|c|c|c|c|}
\hline $\begin{array}{c}\text { Gestational } \\
\text { age (weeks) }\end{array}$ & $\begin{array}{c}\text { Population } \\
(\%)\end{array}$ & $\begin{array}{c}\text { Population with } \\
\text { normal vitamin } \\
\text { B12(\%) }\end{array}$ & $\begin{array}{c}\text { Population with low } \\
\text { vitamin B12 level } \\
(\%)\end{array}$ \\
\hline$<8$ & 32 & $37.50(\mathrm{n}=12)$ & $62.50(\mathrm{n}=20)$ \\
\hline $8-14$ & 68 & $38.24(\mathrm{n}=26)$ & $61.76(\mathrm{n}=42)$ \\
\hline
\end{tabular}

The $\mathrm{p}$ value is .94 . The level of serum vitamin b12 in relation to gestational age is not significant at $\mathrm{p}$-value $<0.05$.

Parity

\begin{tabular}{|c|c|c|c|}
\hline Parity & $\begin{array}{c}\text { Population } \\
(\%)\end{array}$ & $\begin{array}{c}\text { population with } \\
\text { normal vitamin } \\
\text { B12(\%) }\end{array}$ & $\begin{array}{c}\text { Population with low } \\
\text { vitamin B12 level (\%) }\end{array}$ \\
\hline Primigravida & 62 & $48.84(\mathrm{n}=30)$ & $51.16(\mathrm{n}=32)$ \\
\hline Multigravida & 38 & $47.36(\mathrm{n}=18)$ & $52.64(\mathrm{n}=18)$ \\
\hline
\end{tabular}

The $\mathrm{p}-$ value 0.87 . the result is not significant at $\mathrm{p}$-value $<0.05$.

\section{Body Mass Index}

\begin{tabular}{|c|c|c|c|}
$\begin{array}{c}\text { Body mass } \\
\text { index }(\mathrm{kg} / \mathrm{m} 2)\end{array}$ & $\begin{array}{c}\text { Population } \\
(\%)\end{array}$ & $\begin{array}{c}\text { Population with } \\
\text { normal vitamin } \\
\text { B12 }(\%)\end{array}$ & $\begin{array}{c}\text { Population with } \\
\text { low vitamin B12 } \\
\text { level }(\%)\end{array}$ \\
\hline Underweight & 04 & $100(\mathrm{n}=4)$ & $\operatorname{Nil}(\mathrm{n}=0)$ \\
\hline Normal & 62 & $42.39(\mathrm{n}=30)$ & $57.61(\mathrm{n}=32)$ \\
\hline Overweight & 33 & $9.10(\mathrm{n}=03)$ & $90.90(\mathrm{n}=30)$ \\
\hline Obese & 01 & $\operatorname{Nil}(\mathrm{n}=0)$ & $100(\mathrm{n}=01)$ \\
\hline
\end{tabular}

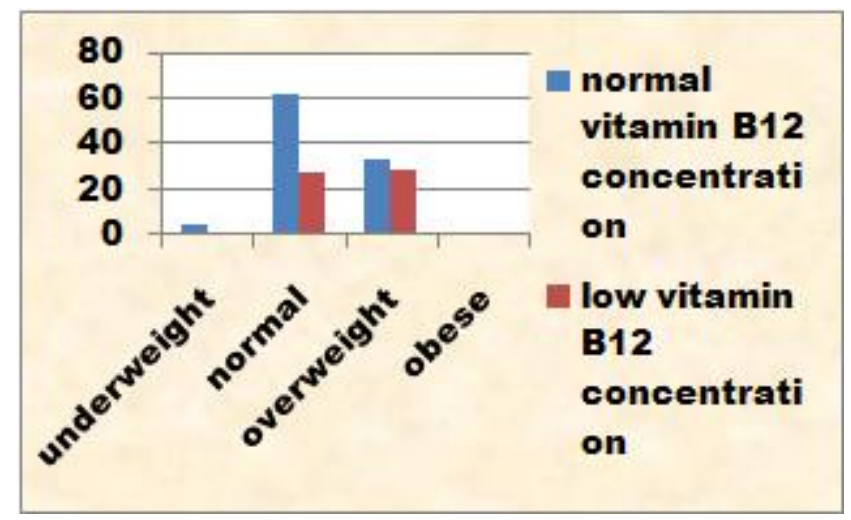




\section{International Journal of Science and Research (IJSR) \\ ISSN (Online): 2319-7064 \\ Index Copernicus Value (2015): 78.96 | Impact Factor (2015): 6.391}

The dietary habits grossly affect the vitamin B12 concentration. $82 \%$ of vegetarian population had low levels of vitamin B12 concentration as compared to $0.05 \%$ women consuming non vegetarian diet. The result is significant at $\mathrm{p}$ value of $<0.05$.

Dietary Habits
\begin{tabular}{|c|c|c|c|}
\hline Dietary habits & $\begin{array}{c}\text { Population } \\
(\%)\end{array}$ & $\begin{array}{c}\text { population with } \\
\text { normal vitamin } \\
\text { B12(\%) }\end{array}$ & $\begin{array}{c}\text { Population with } \\
\text { low vitamin B12 } \\
\text { level }(\%)\end{array}$ \\
\hline vegetarian & 64 & $9.40(\mathrm{n}=06)$ & $90.60(\mathrm{n}=58)$ \\
\hline Non vegetarian & 36 & $88.19(\mathrm{n}=32)$ & $11.11(\mathrm{n}=04)$ \\
\hline
\end{tabular}

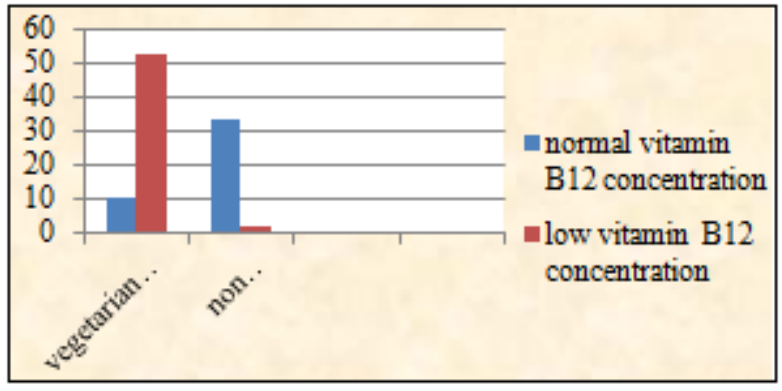

The dietary habits grossly affect the vitamin B12 concentration. $82 \%$ of vegetarian population had low levels of vitamin B12 concentration as compared to $0.05 \%$ women consuming non vegetarian diet.

\section{Results}

The sociodemographic, anthropometric, dietary intake and biochemical data are presented in Table 1.The mean age of women in study group came out to be 22.4years and the mean gestational age was 11.6 weeks. Primipara women constituted $62 \%$ of the population.

The women consuming vegetarian diet was $64 \%$.None of the women was on vitamin B12 supplements in the study group. The mean $\mathrm{Hb}$ was $9.5 \mathrm{~g} / \mathrm{dl}$, and the prevalence of anaemia $(\mathrm{Hb}<11 \mathrm{~g} / \mathrm{dl})$ was $62 \%$. The women presenting with mean corpuscular volume of more than 99fl was about $2 \%$. None of the patient presented with macrocytic anaemia ( $\mathrm{Hb}<11 \mathrm{~g} / \mathrm{dl}$ and MCV $>99 \mathrm{fl})$.

Maternal age, gestational age in weeks, parity, income and education was not significantly associated with low vitamin B12 levels. Higher maternal body mass index was associated with vitamin B12 deficiency. The women having non vegetarian food consumption habits had higher level of vitamin B12 levels. The vitamin B12 concentration falls below the normal value as BMI increases.

\section{Conclusion}

Inadequate dietary intake is one of the most common cause of vitamin B12 deficiency. In our study dietary intake was significantly associated with vitamin B12 concentration. With a dietary intake of $1.25 \mu \mathrm{g} /$ day of vitamin B12, and based on the assumption that $50 \%$ of vitaminB 12 is absorbed in normal healthy adults with normal gastric function, the absorbed vitamin B12 will only be $0.63 \mu \mathrm{g} / \mathrm{day}$, more recently ICMR has defined an intake of $1.2 \mu \mathrm{g} /$ day of vitamin
B12 to meet the requirements of all pregnant Indian women since Indians predominantly consume a vegetarian diet. This is in contrast with WHO/FAO guidelines which are mainly based on population consuming animal diet and the recommended intake is $2.6 \mu \mathrm{g} /$ day for pregnant women.

From a food group perspective, most of the women with intake of food from animal resources was not associated with low vitamin B12 concentration.

Equally interesting was the observation in pregnant women in our study, higher body weight was significantly associated with lower vitamin B12 levels. Vitamin B12 acts as a coenzyme. In vitamin B12 deficiency, there is accumulation of MMA, which can affect mitochondrial respiration and therefore impair substrate oxidation. And it may be possible that obesity or being overweight leads to changes in absorbtion, excretion or metabolism of vitamin B12 and this may be exacerbated with low dietary intake of vitamin B12.

In conclusion, we found a high prevalence of vitamin B12 deficiency among pregnant women with less than 14 weeks of gestation. The association of higher maternal body weight with low vitamin B12 concentration merits further evaluation. Efforts towards improving the vitamin B12 status of pregnant women should be considered by modifying the dietary intake of women.

\section{References}

[1] WHO/FAO . Vitamins and mineral requirements in human nutrition. $2^{\text {nd }}$ edition . WHO. Geneva 2004

[2] Pathak P, Kapil U, Yajnik CS, Kapoor SK, Dwiwedi SN, Singh R . Iro. Folate and vitamin B12 stores among pregnant women in a rural area of Haryana ; India. Food, Nutrition Bull. Dc 2007 28(4) 435-8. [ Pubmed 18274171 ].

[3] Nutrient requirements and recommended dietary allowances for Indians. [ accessed on January 12,2012 ] A report of the expert group of the Indian Council Of Medical Research (Final Draft )2010 . p.208. Available from : http://www.pfindia.com/Draft RDA 2010.pdf.

[4] Hermannn W, Obeid R, Schorr H, Geisel J. Functional vitamin B12 deficiency and determination of holotranscobalamin in population at risk. ClinChem Lab Med. 2003; 41 (11) : 1478-88. [ Pubmed: 14656029]

[5] Walker MC, Smith GN, Perkins SL, Keely EJ ,Garner PR. Changes in homocysteine levels during normal pregnancy. Am J Obstet Gynecol. 1999; 180: 660-4.[ Pubmed: 10076144]

[6] Watanabe F. Vitamin B12 sources and bioavailability .ExpBiol Med ( Maywood) . 2007.

[7] Ruxton CHS. Nutritional implications of obesity and dieting. Nutrition Bulletin .2011; 36(2) : 199-211

[8] Casterline JE, Allen LH, Ruel MT. Vitamin B12 deficiecy is very prevalent in lactating Guatemalan women and their infants at three months postpartum. J Nutr. Oct ; 1997127 (10): 1966-72 [Pubmed : 9311952]

[9] Hjelt K, Paerregaard A, Krasilnikoff PA. Giardiasis: a hematological status and absorbtion of vitamin B12 and folic acid. ActaPaediatr. 1992; 81: 29-34 .[Pubmed : 1600300].

\section{Volume 6 Issue 7, July 2017 www.ijsr.net}




\section{International Journal of Science and Research (IJSR)}

ISSN (Online): 2319-7064

Index Copernicus Value (2015): 78.96 | Impact Factor (2015): 6.391

[10] Veena SR, Krishnaveni GV, Shhrinivas K, Wills AK, Muthayya S, Kurpad AV, Yajnik CS, Fall CH. Higher maternal plasma folate but not vitamin B12 concentration are associated with better cognitive function scores in 9-10 year old children. J Nutr. May 2010 